\title{
ISOLASI DAN IDENTIFIKASI GOLONGAN FLAVONOID PADA EKSTRAK ETIL ASETAT DAUN GEDI (Abelmoschus manihot L.)
}

\author{
Theodora C. T.*, I W. G. Gunawan, dan I M. D. Swantara \\ Program Studi Kimia FMIPA Universitas Udayana, Jimbaran, Bali, Indonesia \\ *e-mail: tinacatriona258@gmail.co.id
}

\begin{abstract}
ABSTRAK
Penelitian ini bertujuan untuk mengetahui senyawa flavonoid yang terkandung dalam ekstrak etil asetat pada daun gedi (Abelmoschus manihot L.). Tahapan yang dilakukan adalah ekstraksi menggunakan metode maserasi dengan pelarut polar yaitu etil asetat teknis, skrining fitokimia flavonoid, pemisahan dan pemurnian dengan metode kromatografi dan identifikasi menggunakan metode spektrofotometer FTIR dan UV-Vis dengan pereaksi geser. Hasil analisis dengan FTIR menunjukkan adanya gugus fungsi seperti $\mathrm{C}=\mathrm{O}, \mathrm{C}-\mathrm{H}$ alifatik, $\mathrm{C}-\mathrm{O}$ alkohol, $\mathrm{C}=\mathrm{C}$ aromatik, $-\mathrm{OH}, \mathrm{C}-\mathrm{O}$ eter. Spektra UV menunjukkan adanya serapan pita I pada panjang gelombang 409,4 $\mathrm{nm}$ dan $238,40 \mathrm{~nm}$ untuk pita II. Dengan demikian, senyawa flavonoid yang terkandung dalam ekstrak etil asetat daun gedi diduga adalah senyawa golongan auron yaitu 3',4,6-trihidroksi, 4-alkoksi-auron
\end{abstract}

Kata kunci: daun gedi, ekstrak etil asetat, flavonoid, isolasi

\begin{abstract}
The purpose of this experiment was to determine the flavonoid compounds in ethyl acetat extract of gedi leaves (Abelmoschus manihot L.). In this study, the method of extraction was maceration with semipolar solvent (ethyl acetat), flavonoid phytochemical screening, separation and purity test with chromatography and then identification of the compound using FTIR and UV-Vis spectrophotometer with shear reagent method. Analysis of FTIR spectra showed some functional groups such as $\mathrm{OH}, \mathrm{CH}$ aliphatic, $\mathrm{C}=\mathrm{O}, \mathrm{CO}$ alcohol, $\mathrm{C}=\mathrm{C}$ aromatic, and $\mathrm{CO}$ ether, whereas the analysis with UV-Vis spectra indicated the presence of band I at a wavelength of $409.4 \mathrm{~nm}$ and $238.40 \mathrm{~nm}$ for band II which is the auron specific wavelength. After the addition of shift reaget, there was a substitutions of $\mathrm{OH}$ groups in C-4, C-6 and C-3' and OR at C-4'. The flavonoid compounds contained in ethyl acetate extract of gedi leaf is suggested to be auron, 3',4,6-trihydroxy,4-alkoxy-auron.
\end{abstract}

Keywords: auron, ethyl acetat extract, flavonoids, gedi leaf, isolation

\section{PENDAHULUAN}

Penggunaan bahan alam sebagai bahan baku obat kini semakin meningkat dengan adanya isu back to nature dalam upaya pencegahan, promosi dan rehabilitasi. Tumbuhan atau bahan alam yang dapat menyembuhkan berbagai macam penyakit mulai dibudidayakan menjadi tanaman obat yang mulai dikembangkan masyarakat sebagai obat tradisonal, fitofarmaka ataupun obat herbal modern terstandarisasi. Namun khasiat dari tanaman obat masih banyak yang belum diteliti secara ilmiah (Mukhriani, 2014).

Oleh sebab itu diperlukan penelitian ilmiah terbaru mengenai khasiat tanaman obat terkait kandungan senyawa, aktivitas penyembuhan, dosis, dan lain-lain dari tanaman obat yang digunakan. Obat-obatan tersebut diketahui salah satunya dapat berasal dari berbagai tumbuhan yang secara alami mengandung flavonoid yang memiliki 15 atom karbon pada inti dasarnya yang mampu berkonjugasi dan berotasi sehingga dapat melepaskan atom hidrogen untuk menstabilkan radikal bebas yang ada di dalam tubuh. Secara umum kerangka dasar flavonoid adalah senyawa polar karena memiliki gugus -OH yang membentuk ikatan hidrogen, namun beberapa flavonoid bebas jenis isoflavon, flavon, flavanon, auron, kalkon, antosianin dan flavonol termetoksilasi merupakan senyawa kurang polar (Monache, 1996).

Daun gedi (Abelmoschus manihot L.) memiliki aktivitas untuk menyembuhkan kolesterol tinggi, sakit ginjal, maag, analgesik, hiperglikemia atau diabetes, asam urat, darah tinggi atau hipertensi, antiinflamasi, 
antioksidan, susah buang air besar, dan sangat disarankan bagi ibu hamil untuk memperlancar kelahiran anak (Suoth, 2013).

Ekstraksi Flavonoid secara umum dilakukan menggunakan pelarut polar seperti etanol karena kebanyakan senyawa flavonoid bersifat polar seperti flavonoid glikosida dan aglikon, namun beberapa flavonoid yang kurang polar sebaiknya diekstrak menggunakan etil asetat, eter dan klorofom, menurut beberapa penelitian seperti penelitian oleh Sennet, 2017 menyatakan bahwa fraksi etil asetat dari buah kersen mengandung flavonoid setelah dilakukan uji skrining fitokimia dan uji kandungan total flavonoid dengan kadar flavonoid menggunakan metode Quarcetin Equivalen sebanyak 0,03\% dari berat sampel fraksi etil asetat. Pasaribu, 2014 menyatakan bahwa pada ekstrak etil asetat daun kerehau (Callicarpa longifolia Lam.) diduga mengandung flavonoid golongan flavonol. Dari uraian di atas peneliti hendak mengidentifikasi golongan flavonoid kurang polar (semi polar) pada ekstrak etil asetat daun gedi untuk membantu perkembangan ilmu kimia mengenai isolasi dan identifikasi flavonoid terkait keberagaman flavonoid.

\section{MATERI DAN METODE}

\section{Bahan}

Bahan yang digunakan adalah daun gedi (Abelmoschus manihot L.) yang diperoleh dari daerah Pesanggaran, Denpasar yang telah dideterminasi di Lembaga Ilmu Pengetahuan Indonesia "Kebun Raya Eka Karya" Bedugul, Bali., etil asetat teknis, metanol, reagen $\mathrm{NaOH}$, $\mathrm{NaOAc}, \mathrm{H}_{3} \mathrm{BO}_{3}, \mathrm{HCl}, \mathrm{AlCl}_{3}$, Aquades, pelarut pro analysis (p.a) seperti kloroform, asam asetat, n-heksan, etanol, etil asetat, dan aseton, serbuk silika gel, metanol dan plat kromatografi lapis tipis (KLT).

\section{Peralatan}

Alat-alat yang digunakan dalam penelitian ini adalah sebagai berikut: wadah maserasi, plat kromatografi lapis tipis (KLT), seperangkat alat kromatografi kolom, lampu UV penampak bercak, neraca analitik, penangas air, oven, penggaris, plat tetes, penguap putar vakum (Vacuum Rotary Evaporator), spektrofotometer UV-Vis dan infra merah (FTIR), oven, neraca analitik, blender, seperangkat alat gelas, aluminium foil, kertas saring, botol fial, dan tisu

\section{Analisis kadar air sampel}

Analisis kadar air menggunakan metode oven kering pada suhu $105^{\circ} \mathrm{C}$. Cawan kosong dikeringkan dengan suhu $105^{\circ} \mathrm{C}$ selama 1 jam lalu didinginkan di dalam desikator selama 2030 menit untuk menstabilkan massa konstan cawan. Setelah itu cawan tersebut ditimbang.

Sebanyak 3 gram sampel dimasukkan ke dalam cawan, ditimbang dengan cepat dan dikeringkan dengan oven $105^{\circ} \mathrm{C}$ selama 3 jam. Kemudian dimasukkan ke dalam desikator selama 20-30 menit dan ditimbang kembali.

Cawan dimasukkan kembali ke dalam oven selama 1 jam sampai diperoleh berat konstan.

Kadar air sampel dihitung dengan rumus berikut :

Keterangan :

$$
\text { Kadar air }=\frac{a-b}{a} \times 100 \%
$$

$\mathrm{a}=$ berat awal sampel (gram)

$\mathrm{b}=$ berat sampel kering yang sudah konstan (gram)

\section{Ekstraksi sampel}

Metode ekstraksi yang digunakan adalah maserasi yang dimodifikasi waktu maserasinya. Sebanyak $1 \mathrm{~kg}$ serbuk sampel daun gedi diekstraksi menggunakan pelarut etil asetat teknis selama 48 jam dan sesekali diaduk, kemudian disaring untuk mengambil filtratnya. Filtrat diuapkan dengan Rotary Evaporator sehingga diperoleh ekstrak kental, kemudian dipanaskan dalam oven suhu $40^{\circ} \mathrm{C}$ selama 24 jam. Rendemen ekstrak yang diperoleh dihitung dengan menggunakan rumus :

\%rendenen $=\frac{\text { berat ehstrak }(g)}{\text { berat serbuk }(g)} \times 100 \%$

(Romansyah, 2011)

\section{Skrining fitokimia flavonoid}

Uji Fitokimia dilakukan pada ekstrak etil asetat daun gedi hasil maserasi sesuai dengan prosedur Harbone (1987) yaitu sebagai berikut:

\section{a. Pereaksi Wilstater}

Sejumlah tertentu sampel ditambahkan beberapa tetes $\mathrm{HCl}$ pekat dan sedikit serbuk Mg. Perubahan warna menjadi kuning menandakan sampel positif flavonoid.

\section{b. Pereaksi Bate Smite-Metcalfe}

Sejumlah tertentu sampel ditambahkan beberapa tetes $\mathrm{H}_{2} \mathrm{SO}_{4}$ pekat, kemudian dipanaskan di atas penangas air selama 15 menit. Reaksi positif jika berwarna merah. 


\section{c. Pereaksi $\mathrm{NaOH} 10 \%$}

Sejumlah tertentu sampel ditambahkan beberapa tetes pereaksi $\mathrm{NaOH} 10 \%$. Setelah itu sampel ditotolkan pada plat tetes. Reaksi positif jika terjadi perubahan warna orange/jingga pada plat tetes.

\section{Isolasi flavonoid}

Ekstrak daun gedi yang positif mengandung flavonoid kemudian dipisahkan dan dimurnikan secara kromatografi dengan cara berikut :

\section{- Kromatografi lapis tipis}

Teknik pemisahan dan pemurnian secara kromatografi lapis tipis (KLT) digunakan untuk memperoleh fase gerak (eluen) yang sesuai sehingga dapat memisahkan senyawasenyawa pada sampel, dengan melihat nilai Rf. Fase diam yang digunakan yaitu silika gel $\mathrm{GF}_{254}$. Sedikit sampel/ekstrak daun gedi yang mengandung flavonoid dilarutkan dengan pelarut yang digunakan, kemudian sampel ditotolkan pada plat KLT, dan diletakkan di dalam bejana yang telah dijenuhkan dengan eluen, plat KLT dibiarkan di dalam bejana tesebut hingga eluen sampai pada tanda batas yang telah tentukan. Plat KLT kemudian dikeluarkan dari bejana dan dikering anginkan lalu disinari di bawah lampu ultraviolet pada panjang gelombang $254 \mathrm{~nm}$ maka noda yang ada pada plat KLT akan tampak. Rf dihitung menggunakan rumus sebagai berikut :

$$
\mathrm{R}_{\mathrm{f}}=\frac{\text { Javak pergerakan noda }}{\text { larak Pergerakan eluen }}
$$

(Touchstone, 1983)

\section{- Kromatografi kolom}

Silika gel $_{60}$ sebanyak 60 gram yang digunakan terlebih dahulu dikeringkan dengan oven $105^{\circ} \mathrm{C}$ selama empat jam, didinginkan pada desikator untuk mengaktivasi dan mengurangi kadar air dalam silika tersebut, kemudian ditambahkan dengan sedikit fase geraknya sampai berbentuk seperti bubur. Selanjutnya fase gerak dimasukkan ke dalam kolom yang bagian bawah kolom telah tersumbat kapas. Aliran pelarut dalam kolom diatur kecepatan alirannya dan bubur dimasukkan sedikit demi sedikit kedalam kolom sampai seluruh bubur masuk ke dalam kolom. Setelah seluruh bubur masuk, fase diam dielusi sampai terjadi pemampatan dengan sempurna.
Sampel sebanyak 1,5 gram dilarutkan dengan sedikit pelarutnya kemudian dimasukkan dengan hati-hati melalui tepat di atas (tepat di bagian tengah) kolom, sementara aliran fase gerak diatur $1 \mathrm{~mL} / \mathrm{menit}$. Begitu sampel masuk kedalam fase diam, fase gerak ditambahkan secara terus menerus sampai terjadi pemisahan. Eluat ditampung pada penampung fraksi setiap $3 \mathrm{~mL}$. Eluat yang diperoleh dilihat pola nodanya pada KLT. Kemudiandigabungkan berdasarkan kesamaan pola noda sehingga diperoleh beberapa fraksi, semua fraksi diuapkan pelarutnya, dan diuji secara fitokimia (Markham, 1988).

\section{- Skrining fitokimia flavonoid pada eluat ekstrak etil asetat \\ Uji Fitokimia senyawa golongan \\ flavonoid dilakukan pada eluat hasil kromatografi kolom menggunakan pereaksi Wilstater, Bate Smite-Metcalfe dan $\mathrm{NaOH} 10 \%$}

\section{- Kromatografi lapis tipis kemurnian}

Fraksi yang paling positif flavonoid diuji kemurniannya pada KLT untuk mengetahui kemurniannya yang ditandai dengan adanya hanya 1 noda pada plat KLT. Sampel ditotolkan pada plat KLT silika gel $\mathrm{GF}_{254}$ dengan berbagai campuran fase gerak.

\section{Identifikasi}

Fraksi yang relatif murni diidentifikasi dengan menggunakan spektrofotometer FTIR dan UV-Vis.

\section{a. Pengukuran dengan spektrofotometer FTIR}

Fraksi berbentuk padat yang relatif murni dan mengandung flavonoid digerus bersama dengan kalium bromida sampai homogen, selanjutnya diukur dengan spektrofotometer FTIR.

\section{b. Pengukuran spektrum UV-Vis Identifikasi senyawa dengan} menggunakan metode spektrofotometri UVVis yaitu melihat adanya 2 pita serapan yang khas dimiliki oleh senyawa golongan flavonoid. Adanya gugus substituen yang terikat pada golongan flavonoid dipergunakan pereaksi geser aluminium klorida, natrium hidroksida, natrium asetat, dan asam borat (Markham, 1988). 


\section{HASIL DAN PEMBAHASAN}

\section{Analisis Kadar Air Sampel}

Serbuk kering daun gedi sebanyak 3 gram dikeringkan di dalam oven $105^{\circ} \mathrm{C}$ dan setelah 3 jam dihasilkan massa serbuk kering daun gedi sebesar 2,75 gram, kemudian sampel dioven kembali selama 2x1 jam sehingga didapat massa yang konstan yaitu 2,75 gram, sehingga diperoleh kadar air sebesar 8,3\%. Hal ini menunjukan bahwa persentase kadar air dalam serbuk daun gedi telah memenuhi standar simplisia, dimana menurut Sudarmadji (2003) kadar air minimal untuk standar simplisia tidak boleh lebih dari $10 \%$. Kadar air merupakan parameter fisikokimia yang berhubungan langsung dengan stabilitas senyawa aktif dalam bahan herbal selama proses penyimpanan. Kadar air yang berlebihan dapat menyebabkan mudahnya pertumbuhan mikroba di dalam simplisia dan hidrolisis senyawa aktif sehingga senyawa akan semakin cepat rusak, sulit terekstrak dan menghasilkan ekstrak dalam jumlah yang sedikit (Dhamuri, 2014)

\section{Ekstraksi Sampel}

Serbuk kering daun gedi diekstraksi dengan metode maserasi dengan pelarut etil asetat teknis sebanyak 6 liter dan diperoleh rendemen sebesar $5,0460 \%(\mathrm{~b} / \mathrm{b})$ yaitu dari massa simplisia kering sebanyak 500 gram yang menghasilkan 25,23 gram ekstrak kental. Pelarut etil asetat bersifat semi polar, digunakan untuk menarik zat aktif dari daun gedi yang bersifat semi polar, salah satunya golongan flavonoid semi polar. Kesamaan kepolaran antara pelarut dengan zat aktif akan mempermudah pengikatan zat aktif tersebut, sehingga ekstrak yang dihasilkan pun akan bersifat semi polar. Rendemen ekstrak digunakan sebagai parameter efisiensi ekstraksi dan standar mutu ekstrak untuk memperkirakan jumlah simplisia kering yang dibutuhkan untuk menghasilkan ekstrak kental dengan jumlah tertentu.

\section{Skrining Fitokimia Flavonoid}

Hasil uji fitokimia flavonoid menunjukkan bahwa ekstrak etil asetat daun gedi mengandung flavonoid, dimana terjadi perubahan warna menjadi kuning sampai merah pada pereaksi Wilstater yang berfungsi untuk mereduksi inti benzopiron pada struktur flavonoid.
Pereaksi Bate Smite-Metcalfe merupakan $\mathrm{H}_{2} \mathrm{SO}_{4}$ yang kemudian dipanaskan, $\mathrm{H}_{2} \mathrm{SO}_{4}$ merupakan katalis asam yang menyebabkan terjadinya reaksi subtitusi elektrofilik yang ditandai dengan perubahan warna menjadi merah.

Pereaksi $\mathrm{NaOH} 10 \%$ merupakan katalis basa yang menyebabkan terjadinya penguraian senyawa flavonoid menjadi molekul asetofenon yang berwarna kuning sampai coklat.

\section{Isolasi flavonoid}

Ekstrak daun gedi yang positif mengandung flavonoid kemudian dipisahkan dan dimurnikan secara kromatografi, kemudian diisolasi dengan cara berikut :

\section{- Kromatografi lapis tipis}

Ekstrak etil asetat daun gedi dipisahkan dengan KLT untuk memperoleh eluen yang sesuai sehingga dapat memisahkan senyawasenyawa pada sampel, dengan melihat nilai $\mathrm{Rf}$ dan noda yang tampak ketika plat KLT disinari sinari UV dengan panjang gelombang $254 \mathrm{~nm}$.

Ekstrak dapat dipisahkan dengan baik menggunakan fase gerak campuran etanol dan n-heksan (2:8) karena fase gerak ini menghasilkan 6 noda yang terpisah secara baik, sehingga eluen tersebut dapat digunakan untuk memisahkan sampel menggunakan kromatografi kolom.

\section{- Kromatografi kolom}

Fase diam yang dipakai dalam kromatografi kolom adalah silika gel ${ }_{60}$ dan fase geraknya menggunakan eluen terbaik hasil kromatografi lapis tipis yaitu etanol : n-heksan

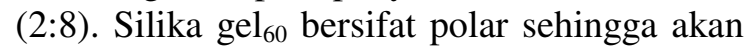
menyerap senyawa-senyawa polar lebih kuat dibanding senyawa semi polar dan non polar. Senyawa-senyawa yang bersifat semi polar dan non polar akan keluar terlebih dahulu dari kolom karena sedikit terserap ke dalam fase diam.

Pemisahan komponen-komponen sampel dengan kromatografi kolom menghasilkan 127 botol eluat. Eluat hasil kromatografi kolom dilihat pola nodanya menggunakan KLT, dengan fase gerak yang digunakan etanol : nheksan (2:8). Eluat digabungkan berdasarkan kesamaan pola noda sehingga didapatkan 4 fraksi (Fa, Fb, Fc dan Fd) seperti pada Tabel 1. 
Tabel 1. KLT Hasil Penggabungan Fraksi Kromatografi Kolom

\begin{tabular}{ccccc}
\hline F & $\begin{array}{c}\text { Botol } \\
\text { ke- }\end{array}$ & $\begin{array}{c}\text { Warna } \\
\text { eluat }\end{array}$ & $\begin{array}{c}\text { Jumlah } \\
\text { noda }\end{array}$ & $\begin{array}{c}\text { Harga } \\
\text { Rf }\end{array}$ \\
\hline a & \multirow{2}{*}{$1-15$} & $\begin{array}{c}\text { Hijau } \\
\text { pekat }\end{array}$ & 2 & 0,9750 \\
b & $16-66$ & $\begin{array}{c}\text { Hijau } \\
\text { agak pekat }\end{array}$ & 2 & 0,9500 \\
c & $67-116$ & $\begin{array}{c}\text { Hijau } \\
\text { muda }\end{array}$ & 2 & 0,9500 \\
& $117-$ & $\begin{array}{c}\text { Hijau } \\
\text { muda }\end{array}$ & 1 & 0,9375 \\
d & 127 & 1 & 0,9125 \\
\hline
\end{tabular}

- Skrining fitokimia flavonoid pada eluat kolom

Uji Fitokimia senyawa golongan flavonoid dilakukan pada eluat hasil kromatografi kolom sesuai dengan prosedur Harbone (1987) yaitu sebagai berikut:

Pengujian keempat kelompok fraksi(F) yaitu $\mathrm{Fa}, \mathrm{Fb}, \mathrm{Fc}$ dan $\mathrm{Fd}$ hasil dari kromatografi kolom (pada Tabel 2) diperkirakan fraksi $\mathrm{Fa}$, $\mathrm{Fb}$ dan $\mathrm{Fc}$ mengandung senyawa flavonoid golongan isoflavon yang memberikan perubahan warna secara berturut-turut kuning menjadi merah bata yaitu dengan pereaksi Wilstatter, kuning dengan pereaksi Bate-SmithMetchalf, dan kuning dengan pereaksi $\mathrm{NaOH}$ 10\%. (Harbone, 1987)

Sedangkan Fd kemungkinan adalah senyawa flavonoid golongan auron yang tidak memberikan perubahan dengan pereaksi Wilstatter, merah-magenta dengan pereaksi Bate-Smite Metchalf, dan merah-ungu dengan pereaksi $\mathrm{NaOH} 10 \%$. Fraksi $\mathrm{Fc}$ yang menunjukkan 1 noda pada KLT selanjutnya diuji kemurniannya.

Tabel 2. Hasil Uji Flavonoid Fraksi Kromatografi Kolom

\begin{tabular}{|c|c|c|c|c|}
\hline \multirow{2}{*}{$\mathrm{F}$} & \multicolumn{3}{|c|}{ Perubahan Warna } & \multirow{2}{*}{$\begin{array}{c}\text { Dugaan Senyawa } \\
\text { Flavonoid } \\
\end{array}$} \\
\hline & Wilstatter & Bate-Smith-Metchalf & $\mathrm{NaOH} 10 \%$ & \\
\hline A & kuning kemerahan & kuning kemerahan & $\begin{array}{l}\text { kuning tua } \\
\text { kemerahan }\end{array}$ & isoflavon \\
\hline B & kuning kemerahan & $\begin{array}{l}\text { kuning muda } \\
\text { kemerahan }\end{array}$ & kuning sedang & isoflavon \\
\hline C & $\begin{array}{l}\text { kuning muda } \\
\text { kemerahan }\end{array}$ & kuning muda & kuning sedang & isoflavon \\
\hline D & $\begin{array}{l}\text { tidak ada } \\
\text { perubahan }\end{array}$ & merah & merah keunguan & auron \\
\hline
\end{tabular}

\section{- Uji kemurnian}

Uji kemurnian dengan KLT menggunakan berbagai eluen. Data hasil uji kemurnian dipaparkan pada Tabel 3.

Tabel 3. Hasil Uji Kemurnian Fraksi Fc dengan Berbagai Eluen

\begin{tabular}{ccc}
\hline Fase gerak & $\begin{array}{c}\text { Jumlah } \\
\text { noda }\end{array}$ & $\begin{array}{c}\text { Harga } \\
\text { Rf }\end{array}$ \\
\hline etanol:n-heksan (2:8) & 1 & 0,9750 \\
etanol & 1 & 0,9375 \\
n-heksan & 1 & 0,0250 \\
etanol:n-heksan (4:6) & 1 & 0,9625 \\
etanol:etil asetat:n- & 1 & 0,9500 \\
\hline heksan (2:2:6) & & \\
\hline
\end{tabular}

Berdasarkan hasil uji kemurnian, maka fraksi $\mathrm{Fc}$ dapat dikatakan relatif murni secara KLT karena menghasilkan satu noda dengan berbagai eluen sehingga dapat dilanjutkan untuk identifikasi senyawa menggunakan spektrofotometer FTIR dan UV-Vis.

\section{Identifikasi}

Fraksi Fc yang relatif murni diidentifikasi dengan menggunakan spektrofotometer FTIR dan UV-Vis.

\section{a. Identifikasi dengan FTIR}

Analisis dengan menggunakan FTIR dilakukan untuk mengetahui gugus fungsi yang terkandung pada fraksi Fc. Spektrum inframerah Fc ditunjukan pada gambar 1.

Hasil identifikasi dengan menggunakan FTIR diduga $\mathrm{Fc}$ mengandung gugus-gugus fungsi seperti $\mathrm{C}-\mathrm{H}$ alifatik, $-\mathrm{OH}$ bebas, $\mathrm{C}-\mathrm{O}$ alkohol, $\mathrm{C}=\mathrm{C}$ aromatik, $\mathrm{C}-\mathrm{H}$ aromatik, $\mathrm{C}-\mathrm{O}$ eter

dan $\mathrm{C}=\mathrm{O}$ yang merupakan gugus fungsi pada kerangka dasar senyawa flavonoid jenis auron. 


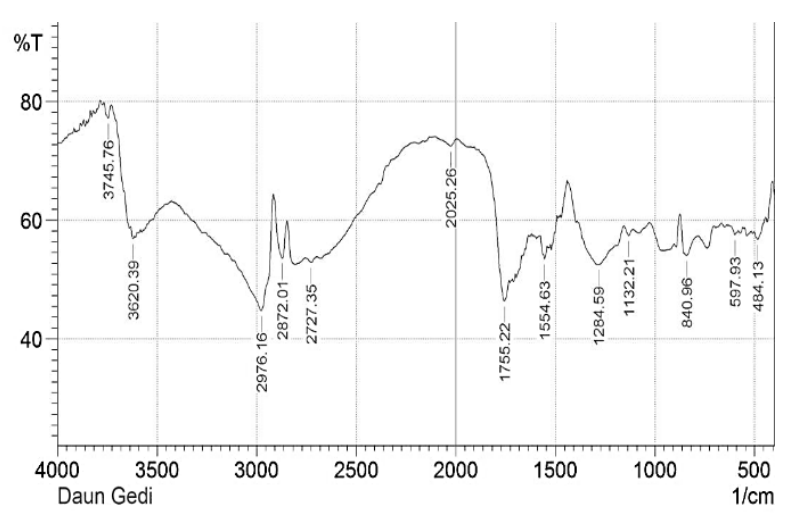

Gambar 1. Spektrum inframerah dari Fc

\section{a. Identifikasi dengan UV-Vis}

Hasil identifikasi Fc dengan spektroskopi UV-Vis seperti ditunjukkan pada gambar 2 menunjukkan bahwa pada fraksi Fc terdapat 2 pita serapan pada panjang gelombang 238,4 nm (pita II) dan serapan dengan bentuk bahu pada panjang gelombang 409,4 $\mathrm{nm}$ (pita I) yang merupakan pita serapan khas auron (Markham, 1988 dan Susmayanti, 2012). Hasil identifikasi dengan FTIR memperkuat dugaan bahwa $\mathrm{Fc}$ adalah senyawa flavonoid golongan auron karena senyawa auron memiliki kerangka dasar dengan gugus fungsi $\mathrm{C}-\mathrm{H}$ aromatik, $\mathrm{C}=\mathrm{C}$ aromatik, gugus $\mathrm{C}=\mathrm{O}$ dan $\mathrm{C}-\mathrm{O}$ eter.

Tabel 4. Data dan Pergeseran Panjang Gelombang Fc Setelah Ditambahkan Pereaksi Geser

\begin{tabular}{|c|c|c|c|c|}
\hline \multirow[t]{2}{*}{ Pereaksi geser } & \multicolumn{2}{|c|}{$\begin{array}{l}\text { Panjang } \\
\text { gelombang } \\
\lambda_{\text {maks }}(\mathbf{n m})\end{array}$} & \multicolumn{2}{|c|}{$\begin{array}{c}\text { Geseran } \\
\text { panjang } \\
\text { gelombang } \\
\lambda_{\text {maks }}(\mathbf{n m})\end{array}$} \\
\hline & Pita I & $\begin{array}{c}\text { Pita } \\
\text { II }\end{array}$ & $\begin{array}{c}\text { Pita } \\
\text { I }\end{array}$ & Pita II \\
\hline Etanol & 409,40 & 238,40 & & - \\
\hline Etanol $+\mathrm{NaOH}$ & 402,20 & 239,20 & $-7,2$ & $+0,8$ \\
\hline $\begin{array}{l}\text { Etanol }+\mathrm{NaOH} \\
(5 \text { menit })\end{array}$ & 401,80 & 240,20 & $-7,6$ & $+1,8$ \\
\hline Etanol + NaOAc & 408,80 & 244,80 & $-0,6$ & $+6,4$ \\
\hline $\begin{array}{l}\mathrm{Etanol}+\mathrm{NaOAc} \\
+\mathrm{H}_{3} \mathrm{BO}_{3}\end{array}$ & 410,60 & 242,40 & $+1,2$ & $+4,0$ \\
\hline Etanol $+\mathrm{AlCl}_{3}$ & 410,80 & 238,80 & $+1,4$ & $+0,4$ \\
\hline $\begin{array}{l}\text { Etanol }+\mathrm{AlCl}_{3}+ \\
\mathrm{HCl}\end{array}$ & 416,20 & 241,80 & $+6,8$ & $+3,4$ \\
\hline
\end{tabular}

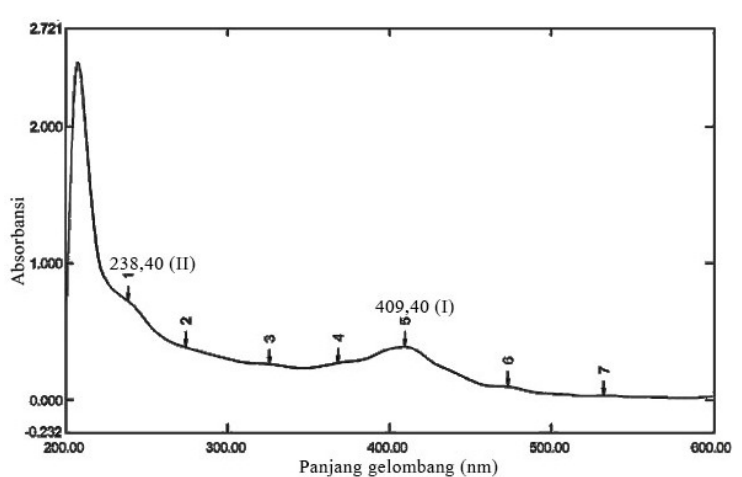

Gambar 2. Spektra UV-Vis dari Fc

Pola oksigenasi dari senyawa flavonoid yaitu dugaan letak gugus hidroksi $(\mathrm{OH})$ bebas pada kerangka auron dapat ditentukan dengan penambahan pereaksi geser seperti $\mathrm{NaOH}$, $\mathrm{NaOAc}, \mathrm{NaOAc} / \mathrm{H}_{3} \mathrm{BO}_{3}, \mathrm{AlCl}_{3}, \mathrm{AlCl}_{3} / \mathrm{HCl}$. Data pergeseran panjang gelombang setelah penambahan pereaksi geser ditunjukkan pada Tabel 4.

Pergeseran serapan pada pita II menunjukkan pola oksigenasi pada cincin A sedangkan pergeseran serapan pada pita I menunjukkan pola oksigenasi pada cincin B. Tabel 4 menunjukkan adanya pergeseran hipsokromik pada pita I dan pergeseran batokromik pada pita II setelah penambahan pereaksi geser $\mathrm{NaOH}$ sebesar -7,2 $\mathrm{nm}$ dan 0,8 $\mathrm{nm}$ terjadi penurunan intensitas setelah 5 menit. Menurut Minanti (2016) dan Markham (1988), pergeseran hipsokromik pada pita I tersebut menunjukkan kemungkinan adanya gugus hidroksi pada C6 dengan oksigenasi pada C4' serta penurunan intensitas pada pita II menunjukkan kemungkinan adanya gugus yang peka terhadap basa seperti 6,7-diOH.

Menurut Susmayanti, pergeseran batokromik setelah penambahan pereaksi geser $\mathrm{NaOAc}$ pada pita II menandakan kemungkinan adanya gugus hidroksi pada C4' dan atau C6$\mathrm{OH}$, sedangkan pergeseran hipsokromik pada pita I menunjukkan kemungkinan tidak adanya gugus $\mathrm{OH}$ pada $\mathrm{C} 7$. Pergeseran batokromik pada pita I dan II setelah penambahan pereaksi geser $\mathrm{NaOAc} / \mathrm{H}_{3} \mathrm{BO}_{3}$ menunjukkan adanya gugus orto dihidroksi pada cincin $\mathrm{B}$ dan atau A. 
Spektrum $\mathrm{AlCl}_{3}$ dan $\mathrm{AlCl}_{3} / \mathrm{HCl}$ merupakan spektrum yang menunjukkan adanya pembentukan kompleks tahan asam antara gugus hidroksil dengan keton yang bertetangga dan membentuk kompleks tak tahan asam dengan gugus orto-dihidroksil, pereaksi ini dapat digunakan untuk mendeteksi kedua gugus tersebut. Menurut Markham (1988), Asih (2015) serta Asih dan Setiawan (2008) pergeseran batokromik terjadi pada pita I dan II setelah penambahan pereaksi geser $\mathrm{AlCl}_{3}$ menandakan terdapat gugus keto pada $\mathrm{C} 3$ dan gugus $\mathrm{OH}$ pada $\mathrm{C} 3$ ' yang membentuk kompleks gugus hidroksi-keto dengan $\mathrm{AlCl}_{3}$. Spektrum $\mathrm{AlCl}_{3}$ merupakan penjumlahan pengaruh semua kompleks terhadap spektrum.

Pergeseran batokromik pada pita I dan II setelah penambahan pereaksi geser $\mathrm{AlCl}_{3} / \mathrm{HCl}$ menunjukkan tidak adanya gugus orto dihidroksi melainkan adanya gugus hidroksiketo pada cincin A dan B karena spektrum $\mathrm{AlCl}_{3} / \mathrm{HCl}$ merupakan pengaruh kompleks hidroksi-keto.

Berdasarkan hasil identifikasi dengan spektrofotometer FTIR dan UV-Vis, diduga senyawa flavonoid $\mathrm{Fc}$ seperti ditunjukkan pada Gambar 3.

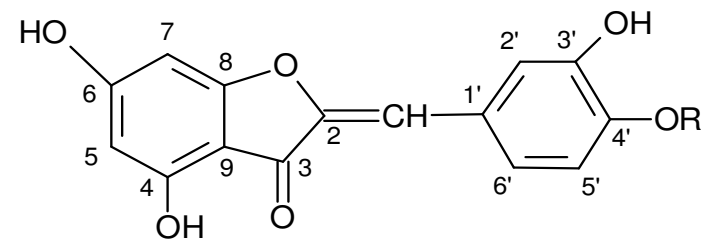

Gambar 3. Dugaan Struktur Senyawa Auron fraksi c (3',4,6-trihidroksi, 4'alkoksi auron)

\section{SIMPULAN DAN SARAN}

\section{Simpulan}

Berdaarkan hasil penelitian yang diperoleh maka dapat disimpulkan bahwa jenis senyawa flavonoid yang terkandung dalam ekstrak etil asetat daun gedi diduga adalah golongan auron yaitu 3',4,6-trihidroksi, 4alkoksi auron yang mengandung gugus fungsi seperti C-H alifatik, -OH bebas, C-O alkohol, $\mathrm{C}=\mathrm{C}$ aromatik, $\mathrm{C}-\mathrm{H}$ aromatik, $\mathrm{C}-\mathrm{O}$ eter dan $\mathrm{C}=\mathrm{O}$ serta tersubsitusi gugus $\mathrm{OH}$ pada $\mathrm{C}-4, \mathrm{C}-$ 6 dan C-3' serta OR pada C-4'.

\section{Saran}

Perlu dilakukan analisis lebih lanjut dengan menggunakan NMR dan LC-MS untuk memperoleh struktur molekul dari fraksi c.

\section{UCAPAN TERIMA KASIH}

Terima kasih kepada semua teman-teman, keluarga, dosen dan staff di program studi Kimia FMIPA Universitas Udayana yang telah membantu dan membimbing selama pengerjaan penelitian ini.

\section{DAFTAR PUSTAKA}

Asih, I. A. R. A. dan Setiawan, I M. A. 2008. Senyawa Golongan Flavonoid Pada Ekstrak n-Butanol Kulit Batang Bungur (Langerstroemia speciose Pers.). Jurnal Kimia, 2(2) : 11-16.

Asih, I. A. R. A., Sudiarta, I W. dan Suci, A. A. W. 2015. Aktivitas Antioksidan Senyawa Golongan Flavonoid Ekstrak Etanol Daging Buah Terong Belanda (Solanum betaceum Cav). Jurnal Kimia, $9(1): 35-40$

Harborne, J. . 1987, Metode Fitokimia Penuntun Cara Modern Menganalisis Tumbuhan, Cetakan ke II, a.b. Kosasih Padmawinata dan Iwang Soediro. ITB, Bandung

Markham, K. R. 1988. Cara Mengidentifikasi Flavonoid. ITB, Bandung.

Monache, D, G., Botta, B., Vinciguerra, V., Mello, J, F. 1996. Antimicrobial Isoflavonones from Desmodium canum. J.Phytochemistry, $41:$ 537-544.

Mukhriani. 2014. Ekstraksi, Pemisahan Senyawa dan Identifikasi Senyawa Aktif. Jurnal Kesehatan, 7 (2) : 361-367

Pasaribu, S. P., Erwin dan Istianti, P. 2014. Isolasi dan Identifikasi Senyawa Flavonoid dari Daun Tumbuhan Kerehau (Callicarpa longifolia Lam.). Jurnal Kimia Mulawarman, 11(2) : 8083.

Romansyah, Y. 2011. Kandungan Senyawa Bioaktif Antioksidan Karang Lunak Sarcophyton sp. Alami dan Transplantasi di Perairan Pulau Pramuka, Kepulauan Seribu. Skripsi, Institut Pertanian Bogor. Bogor

Sennet, M. R. M. 2017. Potensi Senyawa Flavonoid Buah Kersen (Muntingia calabura) sebagai Antioksidan Alami dengan Metode DPPH. Skripsi, Universitas Udayana, Bali

Sudarmadji, S. 2003. Mikrobiologi Pangan. Yogyakarta: PAU Pangan dan Gizi UGM, 
Susmayanti, W., Fachriyah, E., dan Kusrini, D. 2012. Isolasi, Identifikasi dan $\mathrm{Uji}$ Sitotoksik Senyawa Flavonoid dari Ekstrak Etil Asetat Daun Binahong (Anredera condiforlia (Tenns) S.). J.Kimia Sains dan Aplikasi, 15 (3) : 8893.
Suoth, E., Kaempe, H., Tampi, A. 2013. Evaluasi Kandungan Total Polifenol Dan Isolasi Senyawa Flavonoid Pada Daun Gedi Merah (Abelmoschus manihot L.). J.Chem. Prog, 6 (2) : 8691. 